\author{
Іванов А.M. \\ кандидат економічних наук, доцент \\ кафедра туристичного бізнесу та рекреації \\ E-mail: ani1970@mail.ru \\ Саламатіна C.€. \\ кандидат технічних наук, доцент \\ кафедра готельно-ресторанного бізнесу \\ Одеська національна академія харчових технологій \\ вул. Канатна, 112, г. Одеса, Україна, 65039 \\ E-mail: salamatina-svetlana@i.ua
}

\title{
ТЕОРЕТИЧНІ ОСНОВИ ДЕРЖАВНОЇ ПОЛІТИКИ РОЗВИТКУ ТУРИЗМУ НА ОСНОВІ МАРКЕТИНГОВОГО ПІДХОДУ В УПРАВЛІННІ
}

В статті розглянуто теоретичні основи державної політики розвитку туризму з використанням маркетингу в управлінні цією галуззю економіки. Запропоновано створення на основі специфічних функцій, методів, інструментів комплексної моделі реалізації державної політики розвитку туризму в Україні.

Ключові слова: маркетинговий підхід в управлінні, державна політика туризму, управління туризмом, модель державної політики управління туризмом, функція управління, метод управління.

This work is licensed under a Creative Commons Attribution 4.0 International License http://creativecommons.org/licenses/by/4.0/

Постановка проблеми та їі зв'язок з важливими науковими та практичними завданнями. Туризм як сфера народного господарства стимулює основні галузі економіки України та є невід'ємною ланкою розвитку міжнародного співробітництва й інтеграції країни у світову економіку. Це вимагає виваженої державної політики комплексного розвитку сфери туризму. Однак на сьогоднішній день державою не розроблено Закон України, який регламентує основи туристичної діяльності, відсутні єдині підходи в

управлінні цією галуззю як на державному, так і на регіональному рівнях. Саме тому вкрай важливою складовою ефективного розвитку туризму $є$ розробка нової державної політики розвитку туризму на снові маркетингового підходу в управлінні.

Аналіз останніх публікацій 3 проблеми. Значний науковий внесок у дослідження питань, які пов'язані з державною політикою розвитку туризму зробили такі вчені та фахівці як А.Ю. Александрова, В.О. Алексуніна, А.М. Бабашкіна, І.Т. Балабанов, О.О. Бейдик, В.С. Боголюбов, С.О. Бистров, Д.Л. Вилоух, Л.І. Гонтаржевська, П.В. Гудзь, Ю.П. Гуменюк, В.Ф. Данильчук, Л.П. Дядечко, М.І, Кабушкін, В.О. Квартальнов, В.Ф. Кифяк, Т.І. Ткаченко, О.О. Любіцева, М.П. Мальська, Д.М. Стеченко, Т.І. Ткаченко, Л.І. Федулова, С.М. Чистов, С.М. Шкарлет та інші науковці.

Разом $з$ тим, коло проблем, які пов'язані зі створенням та реалізацією державної політики розвитку туризму як галузі національного господарства, яка орієнтована на вирішення загальноекономічних та соціальних питань, не знайшли належного відобра- ження в науковій літературі і не сформували єдиного і цілісного підходу до розуміння і можливості реалізації.

Формулювання цілей дослідження. Метою даного дослідження $є$ розробка комплексної моделі реалізації державної політики розвитку туризму на основі маркетингового підходу з використанням найбільш оптимальних функцій та методів державного регулювання на турдіяльність.

Виклад основних результатів та їх обгрунтування. Зміст державної політики складає сукупність цілей, завдань, пріоритетів розвитку, програм, які розробляють і реалізують органи державної влади iз залученням інститутів громадянського суспільства [1]. Процес формування й реалізації державної політики з розвитку туризму вкладається в «програмний цикл» [2], який включає такі етапи: ініціація політики, розробка політики, виконання політики та оцінка політики.

Реалізація державної політики розвитку туризму як процес може бути визначена у вигляді цілеспрямованої діяльності органів державної влади за наперед прийнятою програмою, яка орієнтована на вирішення суспільних та економічних проблем розвитку туризму, досягнення соціально значущих цілей його розвитку та суспільства в цілому, а також окремих сфер.

Реалізація державної політики розвитку туризму повинна включати організаційно-управлінську модель, нормативно-правову основу, фінансовоекономічне забезпечення та систему державного управління (рис. 1). 


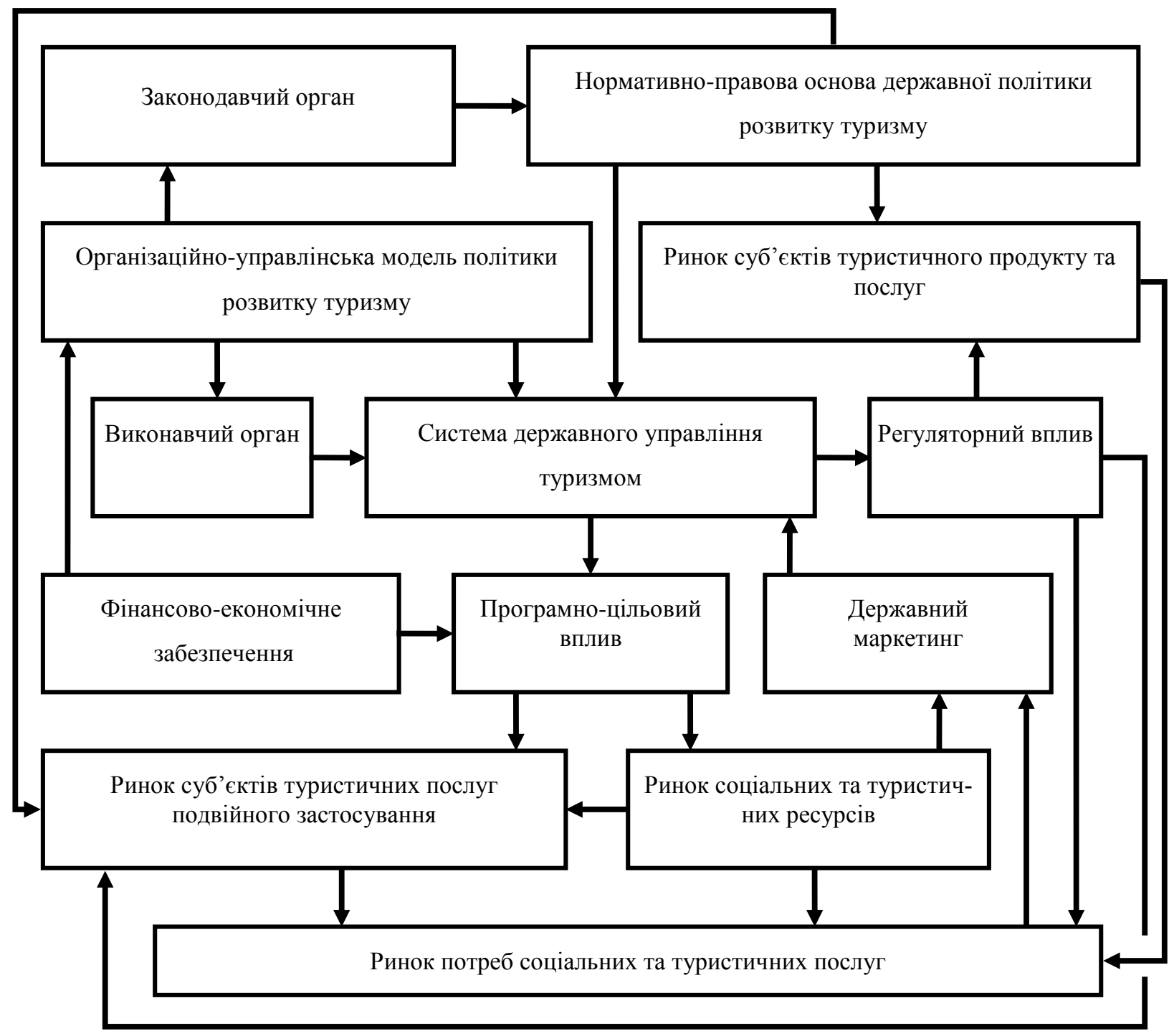

Рис. 1 - Комплексна модель реалізації державної політики розвитку туризму*

* розроблено авторами із використанням джерел [3]

Як видно 3 рис. 1, створена комплексна модель, виявляє більш складну структуру, ніж розглядається в сучасній науковій літературі.

Новизною цієї моделі, перш за все це поділ впливу державного управління, а отже, й державної політики розвитку туризму, на регуляторний вплив, об'єктом управління якого є ринок суб'єктів туристичних продуктів та послуг, й програмно-цільовий, предметом політики, й об'єктом управління якого є ринок суб'єктів туристичних послуг подвійного застосування, з ресурсним, технічним та інфраструктурним забезпеченням.

Крім того, особливістю цієї моделі є поєднання ринку туристичних та соціальних послуг, оскільки туристичні послуги в сутності є соціальними. У моделі також присутній державний маркетинг, який, досліджуючи ринок соціальних та туристичних потреб, а також ринок соціальних та туристичних ресурсів визначає можливість задоволення соціальних та туристичних потреб.

При цьому реалізація державної політики суб'єктами влади може здійснюватися за наступними технологіями: лінійний процес реалізації програм, проектів та планів, процес реалізації певних правил, обумовлених актом та системою взаємозв'язаних заходів.

Зважаючи на комплексний характер розвитку туризму стосовно сфери його діяльності на ринку та законодавства України, доцільно конкретизувати й розширити набір функцій та методів реалізації державної політики регулювання розвитку туризму (табл. 1). 


\begin{tabular}{|c|c|}
\hline Функції & Методи державного регулювання \\
\hline $\begin{array}{l}\text { Загальна організація та } \\
\text { правова регламентація турис- } \\
\text { тичної діяльності }\end{array}$ & $\begin{array}{l}\text { Правове визначення єдиних понять у сфері туризму, } \\
\text { розробка типових угод та процедури їх підписання, затвердження єдиного по- } \\
\text { рядку отримання туристами віз, перетину кордону та провезення товару. }\end{array}$ \\
\hline Планування розвитку туризму & $\begin{array}{l}\text { Розробка стратегій та концепцій розвитку туризму, регулювання розміщення } \\
\text { об’єктів туризму, планування розвитку туристичної інфраструктури. }\end{array}$ \\
\hline $\begin{array}{l}\text { Регулювання окремих видів } \\
\text { діяльності }\end{array}$ & $\begin{array}{l}\text { Регулювання систем ліцензування, стандартизації й сертифікації у сфері тури- } \\
\text { зму. }\end{array}$ \\
\hline Забезпечення безпеки туризму & $\begin{array}{l}\text { Стандартизація та сертифікація продуктів туризму, забезпечення туристів } \\
\text { пам’ятками, страхування, регулювання діяльності служб спасіння, державно- } \\
\text { приватне партнерство з органами МВС. }\end{array}$ \\
\hline Кадрове забезпечення туризму & $\begin{array}{l}\text { Створення державних програм безперервної освіти та перепідготовки кадрів } \\
\text { туризму, сприяння заходам підвищення кваліфікації працівників туристичних } \\
\text { підприємств. }\end{array}$ \\
\hline $\begin{array}{l}\text { Забезпечення наукових дос- } \\
\text { ліджень туристичного ринку }\end{array}$ & $\begin{array}{l}\text { Маркетингові дослідження на туристичному ринку, створення національних } \\
\text { центрів розвитку туризму, інформаційне забезпечення підприємств туризму. }\end{array}$ \\
\hline $\begin{array}{l}\text { Підтримка зовнішньоеконо- } \\
\text { мічної діяльності }\end{array}$ & $\begin{array}{l}\text { Створення представництв за кордоном, укладення міжнародних договорів, } \\
\text { участь при вирішенні конфліктів, реклама туристичних продуктів. }\end{array}$ \\
\hline $\begin{array}{l}\text { Забезпечення охорони до- } \\
\text { вкілля та історичних } \\
\text { пам’ятників }\end{array}$ & $\begin{array}{l}\text { Створення законів, умов економічного стимулювання охорони та відновлення } \\
\text { природних ресурсів, реставрації історичних пам'ятників, розподіл туристичної } \\
\text { ренти, фінансування установ культури. }\end{array}$ \\
\hline $\begin{array}{l}\text { Створення сприятливого імі- } \\
\text { джу країни }\end{array}$ & $\begin{array}{l}\text { Державний маркетинг, реклама, інформаційно-аналітична пропаганда, регу- } \\
\text { лювання оподаткування та інвестування у сферу туризму. }\end{array}$ \\
\hline $\begin{array}{l}\text { Контроль та нагляд за діяль- } \\
\text { ністю й розвитком }\end{array}$ & $\begin{array}{l}\text { Поточний контроль розвитку, аудит економічної діяльності ринку, моніторинг } \\
\text { розвитку міжнародної конкурентоспроможності, туристичних продуктів. }\end{array}$ \\
\hline
\end{tabular}

* опрацьовано авторами із використанням джерел [4]

Крім того, доцільно провести класифікацію сферами їх застосування (табл. 2). інструментів державної політики розвитку туризму за

Класифікація інструментів державної політики туризму за сферами їх застосування *

\begin{tabular}{|c|c|}
\hline Сфера застосування & Інструменти державної політики \\
\hline Правова сфера & $\begin{array}{l}\text { Удосконалення нормативно-правової бази туризму; розвиток методологій лі- } \\
\text { цензування, стандартизації та сертифікації у сфері туризму; митне регулюван- } \\
\text { ня; встановлення правил в’їзду, виїзду та перебування на території України } 3 \\
\text { урахуванням інтересів розвитку туризму; боротьба зі злочинністю та корупці- } \\
\text { єю. }\end{array}$ \\
\hline Економічна сфера & $\begin{array}{l}\text { Податкове регулювання діяльності в туризмі; цільове бюджетне фінансування } \\
\text { програм розвитку туризму; створення сприятливих умов для інвестицій у ту- } \\
\text { ризм; збільшення інвестицій у людський капітал. }\end{array}$ \\
\hline Соціальна сфера & $\begin{array}{l}\text { Вирішення проблем адресного соціального туризму, залучення до вирішення } \\
\text { цих проблем профспілкових і громадських організацій, податкове стимулю- } \\
\text { вання підприємств туризму до надання послуг у сфері соціального туризму. }\end{array}$ \\
\hline Науково-освітня сфера & $\begin{array}{l}\text { Розвиток наукових досліджень у сфері туризму; створення інформаційно- } \\
\text { аналітичної бази; забезпечення професійними кадрами туристичної діяльності. }\end{array}$ \\
\hline Сфера організації туризму & $\begin{array}{l}\text { Формування іміджу України на світовому ринку туризму; сприяння в просу- } \\
\text { ванні туристичного продукту на внутрішній і світовий ринки; участі в міжна- } \\
\text { родних туристських програмах; створення умов для багатоцільового викорис- } \\
\text { тання туристської інфраструктури; координація діяльності та інвестицій дер- } \\
\text { жавного та приватного секторів в області розвитку туризму. }\end{array}$ \\
\hline Інноваційна сфера туризму & $\begin{array}{l}\text { Формування умов інноваційної діяльності у сфері туризму, податкове стиму- } \\
\text { лювання інноваційної діяльності, інвестування в нові види туризму та техно- } \\
\text { логії їх забезпечення. }\end{array}$ \\
\hline
\end{tabular}

*опрацьовано авторами за даними [6; 7] 
Необхідно зауважити, що реалізація державної політики починається після прийняття відповідного нормативного акту, але в процесі розробки політики не менш важливо передбачити правове забезпечення наступних рішень суб'єктів державної влади. При цьому якість системи правового регулювання державної політики відносять до чинників іії ефективності [5].

Міжнародний та внутрішній туризм у кожній конкретній країні грунтується на соціальній політиці, яка пов'язує плани розвитку туристичної індустрії зі стратегічними планами соціально-економічного розвитку.

Виходячи з цього, державна туристична політика в Україні повинна визначити стратегічні цілі та ресурси розвитку туризму, оцінити вплив політики туризму на виробництво, споживання, навколишне та соціальне середовище. Доцільно зауважити, що в сучасній міжнародній практиці державного управління [8] існують інші наукові підходи, за якими політику окремих секторів економіки, включаючи туризм, інтегрують у політику інших секторів, зокрема, у виробничу політику, політику платіжного балансу або планування використання земельних ресурсів.

Як відомо, держана політика туризму орієнтована на економічні, та на неекономічні цілі [9]. До економічних цілей, зокрема, можна віднести заохочення до окремих видів споживання, контроль за торгівлею, зайнятістю та економічним зростанням. До неекономічних цілей слід віднести досягнення свободи переміщення, відродження природної та культурної спадщини тощо.

Держава має здійснювати контроль та регулювати сектор туризму безпосередньо через Міністерство туризму та курортів і національні туристичні організації, а також побічно за допомогою правових важелів, підтримки інфраструктури та міжнародної політики. Механізм регуляторного впливу держави на туризм, на нашу думку, може бути реалізовано за двома підходами: на засадах управління потребами та прибутками та на засадах управління пропозицією та цінами.

Управління потребами в державній політиці здійснюється наступними інструментами: маркетинг та просування, ціноутворення та обмеження доступу. При цьому для проведення ефективного маркетингу необхідними є чітка постановка мети, знання ринку та продуктів туризму. Заходи 3 просування туристичних продуктів $є$ складовою частиною маркетингу, які здійснюе держава, переслідуючи мету збільшення потреб у потенційних туристів.

Для успішного практичного вирішення складних завдань державної політики розвитку необхідно ефективно використовувати досягнення різних галузей знань, серед яких маркетинг займає особливе місце. До основних завдань маркетингу, які $є$ наслідком його сутності як соціально-управлінського процесу при формуванні та реалізації державної політики розвитку туризму доцільно віднести наступні:

- виявлення потреб суб'єктів туристичних ринкових відносин;
- аналіз ситуації на туристичному ринку та тенденцій його розвитку;

- забезпечення просування туристичних продуктів та туристичних послуг до споживача; туристів.

- організацію обміну для задоволення потреб

Підвищити якість та ефективність державної політики без активного використання маркетингу при складності сучасних ринкових процесів та активного втручання в них держави є проблематичним. Держава, як третій суб'єкт маркетингу поряд із продавцями туристичних продуктів та споживачами туристичних послуг виконує на ринку роль регулятора. Безпосередньо не задовольняючи потреби туристів, держава регулює процеси туризму та сприяє досягненню компромісу інтересів між суб'єктами туристичного ринку та економіки в цілому з мінімальними витратами суспільства, що, зокрема обумовлено необхідністю розглядати економічні та соціальні процеси в єдності та взаємодії. При цьому держава, на відміну від окремого туристичного підприємства, зацікавлена в ефективності економіки в цілому. 3 іншого боку, державу доцільно розглядати 3 точки зору надання туристам важливих соціальних послуг.

Наведені обставини приводять до думки про необхідність забезпечення маркетингового підходу в державній політиці та управлінні як у цілому, так і при проведенні окремих заходів розвитку туризму незалежно від їхнього масштабу. У зв'язку з цим необхідно визначити основні цілі та завдання державного маркетингу.

Необхідність використання маркетингу у сфері державної політики розвитку туризму та суб'єктів державного управління обумовлена складною економічною ситуацією країни та процесами глобалізації у світі. Основним напрямом державної політики в ринковій економіці є підтримка та розвиток конкуренції, забезпечення високого рівня конкурентоспроможності національних виробників. Для вирішення цього кола завдань окреме туристичне підприємство має обмежені можливості й ресурси. Тому держава повинна прийняти на себе завдання 3 вирішення складних та масштабних проектів. Для забезпечення рівня конкуренції державна політика має дієві інструменти регулювання, які поділяють на прямі та непрямі методи, та які спрямовані на врегулювання обсягів виробництва туристичних послуг, експорту та імпорту конкретних туристичних продуктів. Тому маркетингова концепція державної політики повинна забезпечити більш ефективне та якісне виявлення, формування та задоволення потреб туристів.

Крім того, маркетинг державної політики туризму повинен сприяти вдосконаленню регіональної спеціалізації виробництва [10]. Це, зокрема актуально в сфері туризму, де ефективність виробництва туристичного продукту та послуг багато в чому залежить від правильного вибору спеціалізації.

Державний маркетинг повинен забезпечити можливість своєчасного реагування на зміни та коливання ситуації на туристичному ринку, більш повно 
враховувати не лише економічні, але й політичні та соціальні чинники. Маркетингові дослідження у сфеpi туризму повинні визначити стратегічні орієнтири на майбутнє, які дозволять формувати перспективні завдання соціальної та економічної політики держави [11].

3 іншого боку, існують різноманітні засоби, за допомогою яких держава може регулювати ціни на туристичний продукт. Наприклад, багато історичних пам'яток в Україні знаходяться у сфері впливу державного сектору економіки, більшість авіакомпаній контролюються державою, а в багатьох країнах, деякі готелі також належать державі. Крім того, соціальна інфраструктура та транспортні мережі вважаються природними монополіями, які, як правило, знаходяться під державним контролем. Держава побічно може вплинути на ціну туристичного продукту за допомогою економічних важелів, наприклад, використовуючи валютний контроль, який може привести до обмеження обміну валюти, внаслідок чого туристи вимушені будуть міняти валюту за завищеною ціною, тим самим, збільшуючи реальну ціну подорожі. Також слід використовувати ліцензування та сертифікацію на засадах градації за якістю обслуговування.

На відміну від управління потребами, яке націлене на вибір туристів та регулювання цін, державне регулювання пропозиції пов'язане з впливом на продавців туристичних продуктів та послуг. В управлінні пропозицією держава використовує наступні методи: аналіз ринку та планування, регулювання ринку, планування та контроль за використанням землі, податки, інвестиції. Держава проводить аналіз ринку на основі збору статистичних матеріалів та моніторингу змін, які відбуваються в туризмі, з метою визначення доходів та витрат туристичної галузі.

Економічним критерієм, який оцінює оптимальну роботу туристичного ринку, є обізнаність туристів про альтернативні послуги. Держава приймає заходи із забезпечення туристів можливістю вибору послуг, інформованістю, та контролю за шахрайством. Для забезпечення конкуренції та захисту ринку від монополізації держава має здійснювати правове регулювання ринком.

Одним 3 методів впливу держави на туризм $є$ оподаткування туристів з метою перерозподілу дохо - ду від туризму у місцеві бюджети, які забезпечують розвиток умов та якість обслуговування туристів. Зокрема, це збори, які стягують $з$ туристів у готелях при розміщенні, в аеропортах при купівлі квитків, тощо. Проте уведення додаткових податків і зборів може негативно вплинути на туристичний ринок та дохідність галузі туризму, оскільки ці заходи призводять до зростання витрат туристів, що, у свою чергу, знижує потреби на туристичний продукт та послуги.

Державна політика розвитку туризму також пов'язана з інвестиціями. Інвестиції в сектор туризму можуть надходити від доходів секторів економіки держави, або від міжнародних організацій. Розмір фінансової допомоги, яка надається державою на розвиток туристичної галузі, визначається важливістю туризму для економіки країни. Державні дотації на розвиток можуть надаватися в різноманітних формах, починаючи від заходів щодо просування позитивного іміджу країни до надання податкових пільг на туристичну діяльність. Серед основних видів державних інвестицій, доцільно виділити наступні: зниження ціни інвестицій у проекти 3 розвитку туризму, яка включає позики за вигідними відсотковими ставками, податкові пільги, продаж землі для розвитку інфраструктури за ціною нижче ринкової, захист від подвійного оподаткування через укладання міжнародних угод із іншими країнами, зниження митних зборів, прямі субсидії та надання державних гарантій на інвестиції з метою залучення зарубіжних інвесторів.

Висновки та перспективи подальших досліджень. Таким чином, для забезпечення державної політики розвитку туризму в Україні необхідно прийняти загальнодержавну стратегію розвитку індустрії туризму збалансовану відносно чинників туристичних потоків та ресурсних можливостей країни, в якій мають бути визначені основні цілі розвитку туризму в короткостроковій та довгостроковій перспективах, механізми, методи та критерії досягнення запланованих результатів, комплекс джерел фінансування та терміни виконання. При цьому, на нашу думку, доцільно спростити процес координації між різними рівнями влади для прискорення стратегічного розвитку туристичних регіонів та повернути для якісного управління цією галуззю Міністерство туризму та курортів України.

\section{Література}

1. Білорус О.Г. Економічна система глобалізму / О.Г. Білоус. - К.: КНЕУ, 2003. - 357 с.

2. Mueller U., Fremdenverkehr in seiner Bedeutung fuer die regionale Strukturpolitik, Frankfurt /M., 2004, S.145-160.

3. Козловський $Є$. Основні напрями розвитку міждержавної політики та управлінських засад у галузі туризму країн СНД / С. Козловський // Вісник Національної академії державного управління при Президентові України. - 2004. - № 4. - С. 398-403.

4. Гуменюк Ю.П. Організаційно-економічні механізми стимулювання розвитку рекреаційнотуристичного комплексу : дис. канд. ек. наук : 08.10.01 / Гуменюк Ю.П. - Львів, 2006. - 198 с.

5. Правове регулювання туристичної діяльності в Україні / За ред. В.К. Федорченка. - К.: Юрінком Інтер, 2002. $-340 \mathrm{c}$.

6. Агафонова Л.Г. Проблеми державного регулювання розвитку туризму в Україні / Л.Г. Агафонова // Культура і освіта фахівців туристичної сфери: сучасні тенденції та прогнози. - К.: КУТЕП, 2005. - С.521-526. 
7. Ковєшніков В.С. Система програмних дій розвитку туристичної галузі в Україні / В.С. Ковєшніков, Ю.Б. Безкоровайна, К.Л. Рубцов // Культура і освіта фахівців туристичної сфери: сучасні тенденції та прогнози. - К.: КУТЕП, 2005. - С.179-185.

8. Данильчук В.Ф. Економіка туризму. Концепція створення міжнародних туристичних центрів в Україні / В.Ф. Данильчук // Наукові записки КУТЕП. Щорічник. - Вип.2. - К.: Знання України, 2002. - С.107-113.

9. Шкарлет С.М. Тенденції і перспективи розвитку туристичної галузі України у складі національної та світової економіки / С.М.Шкарлет, О.М.Кальченко // Актуальні проблеми економіки. - 2009. - № 10. - С.36-43.

10. Гудзь П.В. Механізм розвитку курортно-рекреаційних територій у сучасних умовах : дис. докт. ек. наук : 08.10.01 / Гудзь П.В. - Донецьк, 2003. - 450 с.

11. Окландер М.О. государственном маркетинговом регулировании / М.О.Окландер / Экономика Украины. - 2003. - №4. - С. 80-81.

\author{
Иванов А.Н. \\ кандидат экономических наук, доцент \\ кафедра туристического бизнеса и рекреации \\ E-mail: ani1970@mail.ru \\ Саламатина C.E. \\ кандидат технических наук, доцент \\ кафедра отельно-ресторанного бизнеса \\ Одесская национальная академия пищевых технологий \\ ул. Канатная, 112, г. Одесса, Украина, 65039 \\ E-mail: salamatina-svetlana@i.ua
}

\title{
ТЕОРЕТИЧЕСКИЕ ОСНОВЫ ГОСУДАРСТВЕННОЙ ПОЛИТИКИ РАЗВИТИЯ ТУРИЗМА НА ОСНОВЕ МАРКЕТИНГОВОГО ПОДХОДА В УПРАВЛЕНИИ
}

Реализация государственной политики развития туризма как процесс определяется в виде целенаправленной деятельности органов государственной власти по программе, определенной ранее и ориентированной на решение общественных и экономических проблем развития туризма, достижение социально значимых целей его развития и общества в целом, а также отдельных сфер.

Реализация государственной политики развития туризма должна включать организационноуправленческую модель, нормативно-правовую основу, финансово-экономическое обеспечение и систему государственного управления.

Новизной созданной авторами комплексной модели является разделение влияния государственного управления и как следствие - государственной политики развития туризма на регулятивное влияние, объектом управления которого является рынок субъектов туристических продуктов и услуг, а также программно-целевой, предметом политики и объектом управления которого является рынок субъектов туристических услуг двойственного использования, с ресурсным, техническим и инфраструктурным обеспечением.

Учитывая комплексное развитие туризма относительно сферы его действия на рынке и законодательства Украины, по мнению авторов, необходимо конкретизировать и расширить набор функций и методов реализации государственной политики регулирования развития туризма и провести классификацию инструментов государственной политики развития туризма по сфрерам их использования.

Маркетинг государственной политики туризма должен способствовать усовершенствованию региональной специализации производства и обеспечить возможность своевременного реагирования на изменения и колебания ситуации на туррынке, более полно учитывать не только экономические, но и политические и социальные условия.

Одним из методов влияния государства на туризм является налогообложение туристов с целью перераспределения дохода от туризма в местные бюджеты, которые обеспечивают развитие условий и качества обслуживания туристов.

Также необходимо привлечь инвестиции в сектор туризма, которые могут поступать от секторов экономики государства, или от международных организаций.

Ключевые слова: маркетинговый подход в управлении, государственная политика туризма, управление туризмом, модель политики управления туризмом, функция управления, метод управления. 


\author{
Ivanov A. \\ Ph.D. in Economics, Associate Professor \\ Department of Tourism business and recreation \\ E-mail: ani1970@mail.ru \\ Salamatina S. \\ Ph.D. in Technical Sciences, Associate Professor \\ Department of Hotel-restaurant business \\ Odessa National Academy of Food Technologies \\ Kanatna str., 112 , Odessa, Ukraine, 65039 \\ E-mail: salamatina-svetlana@i.ua
}

\title{
THEORETICAL PRINCIPLES OF STATE TOURISM DEVELOPMENT POLICY BASING ON THE MARKETING APPROACH IN THE MANAGEMENT PRACTICE
}

The implementation of the state tourism development policy as a process can be defined as purposeful activities of state authorities according to the adopted in advance program which shall be directed on the solving of social and economic problems of tourism development, achieving socially important, both for its development and for the development of the society in general, goals and particular spheres as well.

It is important to consider the managerial model, normative legal base, financial and economic support, public administration system in order to put into practice the state tourism development policy.

The novelty of the developed by us complex model is the division of state administration influence. Consequently, state tourism development policy is divided into the regulatory influence whose object of administration is the market of subjects of tourist products and services; and program-oriented influence whose matter of policy and object of administration is the market of subjects of tourist products and services of double usage with resource, technical and infrastructural providing.

Considering the complex nature of tourism development as for the sphere of its activities in the market and Ukrainian legislation, it is reasonable to specify and extend the set of functions and methods of implementation of state tourism development policy regulation and classify the instruments of state tourism development policy in accordance with the spheres of their exercising.

State tourism policy marketing shall encourage the improvement of regional specific features of production operation and shall provide an opportunity to respond, in time, to the changes and hesitations of tourist market situation; shall take into account, to the fullest extent, not only economic, but political and social factors.

One of the methods of state's influence on tourism is taxation of tourists with the purpose to redistribute incomes from tourism into the local budgets which shall provide the development of conditions and quality of tourist services.

It is necessary to raise investments into tourism sector those could come from the incomes of other sectors of state economy or from international organizations.

Key words: marketing approach in management practice, state tourism policy, tourism management, model of state policy as for tourism management, managerial function, managerial method.

\section{References}

1. Bilorus, O. H. (2003). Ekonomichna systema hlobalizmu. K.: KNEU.

2. Mueller, U. (2004). Fremdenverkehr in seiner Bedeutung fuer die regionale Strukturpolitik. Frankfurt: M.

3. Kozlovskyi, I. (2004). Osnovni napriamy rozvytku mizhderzhavnoi polityky ta upravlinskykh zasad u haluzi turyzmu krain SND. Visnyk Natsionalnoi Akademii Derzhavnoho Upravlinnia Pry Prezydentovi Ukrainy, 4, 398-403.

4. Humeniuk, I. P. (2006). Orhanizatsiino-ekonomichni mekhanizmy stymuliuvannia rozvytku rekreatsiinoturystychnoho kompleksu. Lviv.

5. Fedorchenko, V. K. (2002). Pravove rehuliuvannia turystychnoi diialnosti v Ukraini. K.: Yurinkom Inter.

6. Ahafonova, L. H. (2005). Problemy derzhavnoho rehuliuvannia rozvytku turyzmu v Ukraini. Kultura I Osvita Fakhivtsiv Turystychnoi Sfery: Suchasni Tendentsii Ta Prohnozy, 521-526.

7. Kovieshnikov, V. S., Bezkorovaina, I. B., \& Rubtsov, K. L. (2005). Systema prohramnykh dii rozvytku turystychnoi haluzi v Ukraini. Kultura I Osvita Fakhivtsiv Turystychnoi Sfery: Suchasni Tendentsii Ta Prohnozy, 179185.

8. Danylchuk, V. F. (2002). Ekonomika turyzmu. Kontseptsiia stvorennia mizhnarodnykh turystychnykh tsentriv v Ukraini. Naukovi Zapysky KUTEP. Shchorichnyk, (2), 107-113.

9. Shkarlet, S. M., \& Kalchenko, O. M. (2009). Tendentsii i perspektyvy rozvytku turystychnoi haluzi Ukrainy u skladi natsionalnoi ta svitovoi ekonomiky. Aktualni Problemy Ekonomiky, 10, 36-43. Donetsk.

10. Hudz, P. V. (2003). Mekhanizm rozvytku kurortno-rekreatsiinykh terytorii u suchasnykh umovakh.

11. Oklander, M. O. (2003). Hsudarstvennom marketynhovom rehulyrovanyy (Vol. 4).

Received 28 January 2016

Approved 11 February 2016

Available in Internet 29.03.2016 